\title{
Genetic Studies on the Effect of Slow Rusting Genes Lr34 and Lr68 on Minimizing Grain Yield Losses in Back Cross Segregating Populations of the Cross GW322 X Parula in Bread Wheat (Triticum aestivum L.)
}

\author{
Ashutosh Kumar', S.A. Desai ${ }^{*}$, Suma S. Biradar², K.J. Yashavantha Kumar ${ }^{3}$, \\ P.V. Patil ${ }^{2}$, V. Rudra Naik ${ }^{2}$, T.N. Sathisha ${ }^{1}$ and Bhumika N. Patel ${ }^{1}$ \\ ${ }^{1}$ Department of Genetics and Plant Breeding, ${ }^{2}$ ICAR-AICRP on Wheat, MARS, University of \\ Agricultural Sciences, Dharwad-580005, Karnataka, India \\ ${ }^{3}$ Agharkar Research Institute, Pune, India \\ *Corresponding author
}

\section{A B S T R A C T}

Achieving durability of resistance and minimizing yield losses due to Leaf rust, caused by Puccinia triticina Eriks, in wheat has been one of the major objective of breeding programs. The slow rusting genes that are quantitatively inherited, are known to confer

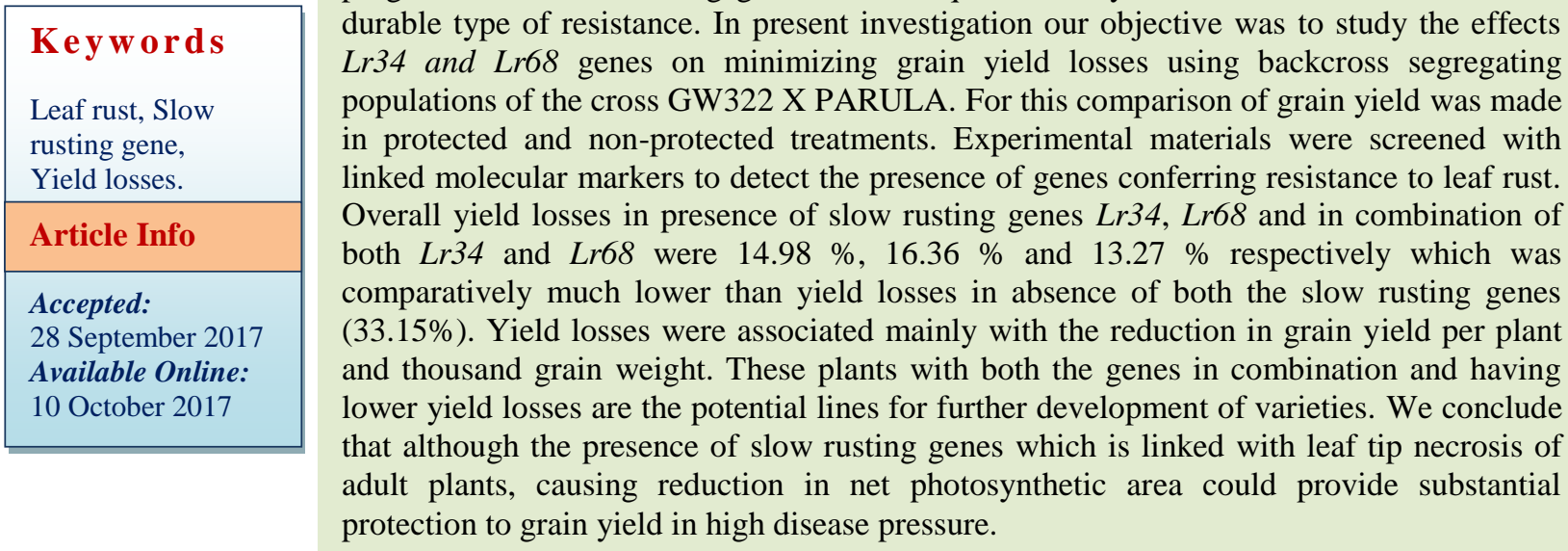

\section{Introduction}

Leaf rust, caused by Puccinia triticina Eriks, is considered to be the most serious disease of wheat (Triticum aestivum L.) and universal in occurrence. Leaf rust, also known as brown rust caused by the heteroecious basidiomycete is most common and widely distributed of the three wheat rusts and has become more serious problem of wheat causing great losses in grain yield ( Huerta-Espino et al., 2011).
Yield losses in wheat from $P$. triticina infections are usually the result of decreased number of kernels per head and lower kernel weight (Roelfs et al., 1992; Marasas et al., 2004; Kolmer et al., 2005). Early infection of leaf rust on wheat generally causes higher yield losses; 60-70\%, infection on the flag leaf at spike emergence may account for a yield loss of more than $30 \%$. 
More than 100 leaf rust resistance genes have been reported in wheat and its relatives, 72 of them permanently catalogued (McIntosh et al., 2013). Most of these leaf rust resistance genes condition a hypersensitive reaction and interact with the pathogen in a gene-for-gene fashion. Erosion of race specific resistance genes, or their combinations, has led to search for alternative approach to resistance management.

An alternative approach is to deploy varieties that possess adult plant resistance (APR) based on combinations of minor, slow rusting genes. When present alone, APR genes do not confer adequate resistance especially under high disease pressure; however, combinations of 4-5 such genes usually result in "near immunity". At present, among the known genes with slow rusting effect the most common are the genes: Lr34 (Dyck, 1987), Lr46 (Singh et al., 1998), Lr67 (Hiebert et al., 2010 and Herrera-Foessel et al., 2011) and Lr68 (Herrera-Foessel et al., 2012). These genes have pleiotropic effects, when pyramided in one line provide more durable and non-race specific adult plant resistance to all three rust (Singh et al., 2011).

The objectives of this study was to determine the effectiveness of race non-specific and slow-rusting resistance in reducing losses in grain yield and to identify superior recombinants for yield and its component traits having both the genes when exposed to high leaf rust pressure.

\section{Materials and Methods}

The present investigation was conducted during rabi season 2015-16 at ICAR-All India Co-ordinated Wheat Improvement Project, Main Agricultural Research Station, University of Agricultural Science (UAS), Dharwad.
The materials of present experiment comprised of 180 lines of different segregating populations of the cross GW322 $\mathrm{X}$ PARULA. These advanced backcross segregating lines were evaluated in Augmented Block Design. These lines were sown in protected condition and artificial epiphytotic condition in 6 blocks, each block consist of 30 lines with 4 checks viz., UAS304, HD2189, GW322 and Parula having spacing of $20 \times 20 \mathrm{~cm}$. Genomic DNA extraction was extracted from fresh leaves using cetyl trimethyl ammonium bromide (CTAB) method (Doyle and Doyle, 1987) with little modifications. Polymerase Chain Reactions (PCR) were performed by using a protocol appropriate for pair of primers. DNA amplification was performed in $20 \mu \mathrm{l}$ reaction mixture. The PCR products were mixed with $2 \mu$ of loading dye $(0.25 \%$ bromophenol blue with $40 \%$ sucrose) and were loaded into each well and separated on 2 per cent agarose gel using $1 \mathrm{X}$ TAE buffer of $\mathrm{pH} 8.0$ containing ethidium bromide. After electrophoresis gel viewed under UV-transilluminator (JH-Bio). The tightly linked marker for the respective gene of interest specific amplicon size was observed on the agarose gel (Plate 1). The allele specific marker cssfr-5 for Lr34 gene was codominant in nature, amplified $751 \mathrm{bp}$ for the presence and $523 \mathrm{bp}$ for the absence of gene. The STS marker csGS for $\operatorname{Lr} 68$ was dominant in nature, amplified 385 bp PCR product for the presence and no product amplification for the absence of the gene.

Susceptible checks were planted after every ten genotypes and all around the experimental plots using the universal susceptible varieties like Lal Bahadur, Agra Local, and Local Red. At days to 50 per cent flowering of the crop, field was maintained under irrigation and the suspension of mixture of pathotypes of leaf rust was sprayed on the genotypes at continuous interval. 
Randomly five plants were selected and observations were recorded for the traits like plant height $(\mathrm{cm})$, days to 50 per cent flowering, days to maturity, no of productive tillers per plant, spike length $(\mathrm{cm})$, number of spikelet per spike, no of seeds per spike, thousand grain weight (g) and grain yield per plant $(\mathrm{g})$.

In this investigation, the difference between grain yield per plant was considered between the protected and epiphytotic plots in presence of different gene $(\operatorname{Lr} 34, \operatorname{Lr} 68)$ and their combination $(L r 34+L r 68)$ and per cent loss was calculated as the difference among the protected and infected treatments using the following equation adopted by Calpouzos et al., (1976).

$\operatorname{Loss}(\%)=\frac{\mathrm{Yh}-\mathrm{Yd}}{\mathrm{Yh}}$

Where,

Yd $=$ yield of disease plants (infected treatment);

Yh = yield of healthy plant (protected treatment).

Correlation studies were also done. The correlation analysis between grain yield per plant and coefficient of infection was done using the SPSS 16.0 version.

\section{Results and Discussion}

Leaf rust pressure was high and uniform throughout the experiment in artificial epiphytotic condition. The fungicideprotected plots remained free from leaf rust during the entire crop season. Plants carrying slow rusting genes viz., Lr34 and Lr68 displayed immune to compatible type of rust reaction. Recurrent parent GW322 displayed moderately susceptible to susceptible type of reaction throughout the experiment, while donar parent Parula displayed immune to partially immune type of reaction. The grain yield per plant and thousand grain weight was comparatively higher for fungicide-protected plots than leaf rust inoculated plots. The difference in yield was expected because leaf rust infection was initiated at different plant development stage in the leaf rust inoculated plots compared with the protected plots. The correlation analysis between grain yield per plant and coefficient of infection was done using the SPSS 16.0 version. The results (Table 1) indicated that both the traits are significantly correlated with each other at 0.01 levels (2-tailed) with a value of $0.318^{* *}$.

In the $\mathrm{BC}_{2} \mathrm{~F}_{4}$ population (Table 2) plants with Lr34 + Lr68 combination recorded least reduction in grain yield per plant $(13.72 \%)$ followed by plants with only Lr34 gene (14.9\%). Plants with Lr68 gene alone recorded reduction in grain yield per plant upto 22.21 per cent. However plants lacking both the genes recorded very high percentage of reduction in yield $(33.15 \%)$.

Progeny 4-14-98 with Lr34 + Lr68 gene recorded lowest reduction in yield with only 5.06 per cent whereas progeny 7-39-87 lacking both the genes recorded highest reduction in yield with 42.25 per cent of loss. In the $\mathrm{BC}_{3} \mathrm{~F}_{3}$ population (Table 3 ) presence of Lr68 gene alone recorded less reduction in grain yield per plant $(10.33 \%)$ compared to plants with $\operatorname{Lr34}(10.67 \%)$ whereas plants with $\operatorname{Lr34}+\operatorname{Lr68}$ recorded 12.16 per cent reduction in yield. However plants lacking both the genes recorded very high percentage of reduction in yield $(33.74 \%)$. Progeny 21 27-157 with $\operatorname{Lr34}$ recorded lowest reduction in yield with only 3.07 per cent of loss. 
Fig.1 Overall yield loss assessment in backcross segregating generation of the cross GW322 X PARULA

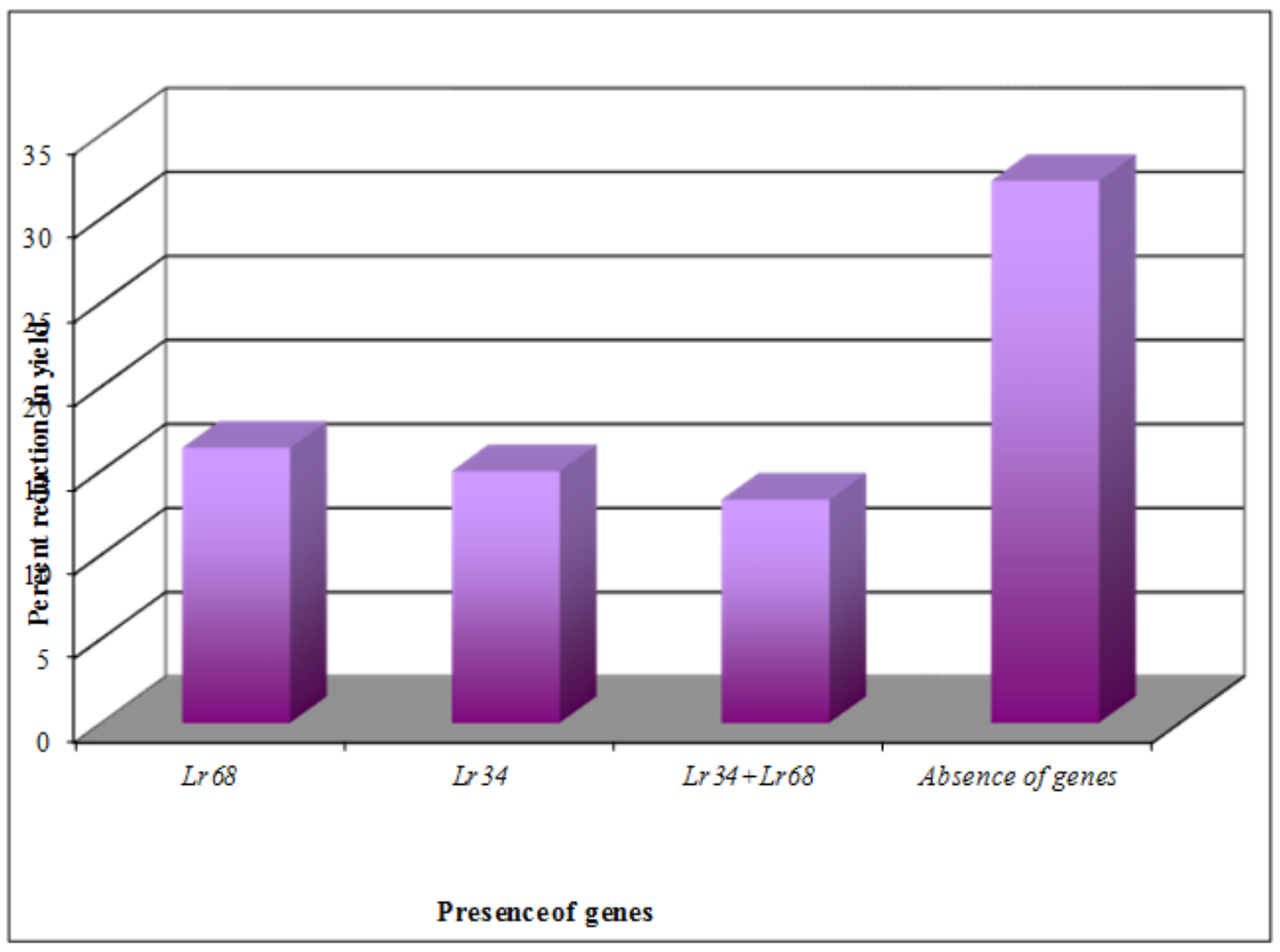

Plate.1 Molecular confirmation of plants for presence of Lr34 and Lr68 genes

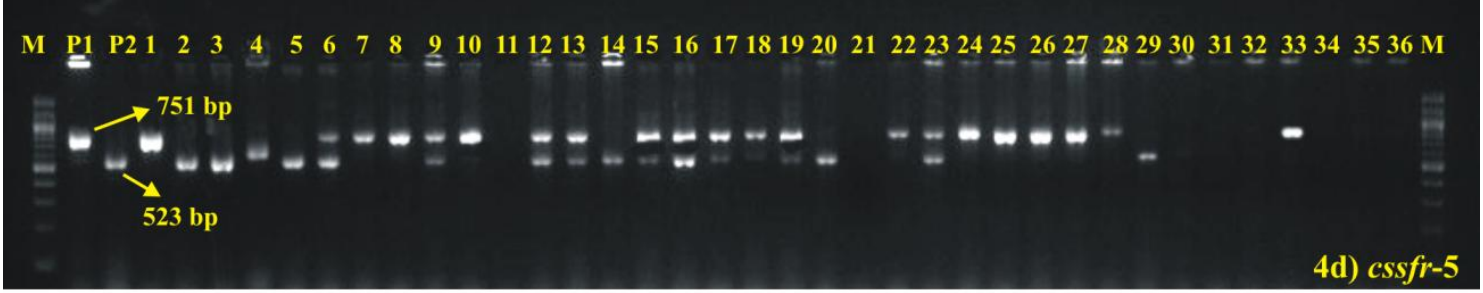

M - 100 bp ladder, P1 (PARULA), P2 (GW 322), Lane 1, 4,,6-10, 12, 13, 15-19, 22-28, 33 Lr34 +ve

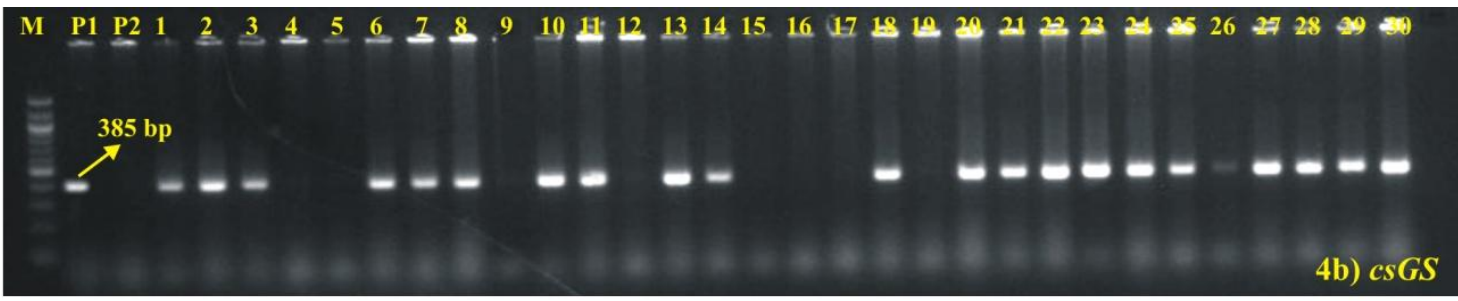

M - 100 bp ladder, P1 (PARULA), P2 (GW 322), Lane 1-3, 6-8, 11-14, 18, 20-22, 24-25, 27-30 Lr68 +ve 
Table.1 Correlation between grain yield and coefficient of infection (CI) in back cross segregating generations of the cross GW322 x PARULA in bread wheat

\begin{tabular}{|c|l|c|c|}
\hline & & CI & Yield \\
\hline \multirow{2}{*}{ CI } & Pearson Correlation & 1 & $\begin{array}{c}-0.318^{* *} \\
68\end{array}$ \\
\hline \multirow{2}{*}{ Yield } & Pearson Correlation & & 1 \\
& $\mathrm{~N}$ & $-0.318^{* *}$ & 68 \\
\hline
\end{tabular}

**. Correlation is significant at the 0.01 level (2-tailed).

Table.2 Grain yield loss assessment in the $\mathrm{BC}_{2} \mathrm{~F}_{4}$ progenies of the cross GW322 x PARULA in bread wheat

\begin{tabular}{|c|c|c|c|}
\hline Generation & Progeny & Minor gene screened & $\begin{array}{c}\text { Percent reduction in } \\
\text { yield }\end{array}$ \\
\hline \multirow{33}{*}{$\mathrm{BC}_{2} \mathrm{~F}_{4}$} & $7-47-85$ & Lr68 & 14.76 \\
\hline & $7-38-80-249$ & $\operatorname{Lr68}$ & 14.81 \\
\hline & $7-38-80-250$ & Lr68 & 26.70 \\
\hline & $7-45-82-258$ & $\operatorname{Lr68}$ & 18.00 \\
\hline & $7-45-82-259$ & Lr68 & 36.35 \\
\hline & & Mean & 22.21 \\
\hline & $7-28-74$ & Lr34 & 5.81 \\
\hline & $7-31-75$ & Lr34 & 19.35 \\
\hline & $7-33-76$ & Lr34 & 16.95 \\
\hline & $7-34-77$ & Lr34 & 11.98 \\
\hline & $7-35-78$ & Lr34 & 15.71 \\
\hline & $7-40-81$ & Lr34 & 14.86 \\
\hline & 95 & $\operatorname{Lr} 34$ & 11.71 \\
\hline & 4-14-93 & Lr34 & 6.51 \\
\hline & $47-149-104$ & Lr34 & 14.51 \\
\hline & $47-147-105$ & Lr34 & 21.41 \\
\hline & $47-139-107$ & $\operatorname{Lr} 34$ & 26.55 \\
\hline & & Mean & 15.03 \\
\hline & $7-37-79$ & Lr34+Lr68 & 17.08 \\
\hline & 7-40-81 & $\operatorname{Lr} 34+\operatorname{Lr} 68$ & 14.86 \\
\hline & $7-45-82-260$ & $\operatorname{Lr} 34+\operatorname{Lr} 68$ & 9.07 \\
\hline & 92-96 & $\operatorname{Lr} 34+\operatorname{Lr} 68$ & 13.90 \\
\hline & $4-15-97-338$ & $\operatorname{Lr} 34+\operatorname{Lr} 68$ & 16.91 \\
\hline & 4-14-98 & $L r 34+\operatorname{Lr} 68$ & 5.06 \\
\hline & 4-13-99 & $\operatorname{Lr} 34+\operatorname{Lr} 68$ & 14.20 \\
\hline & 4-11-100 & $\operatorname{Lr} 34+\operatorname{Lr} 68$ & 18.44 \\
\hline & 47-131-108 & $\operatorname{Lr} 34+\operatorname{Lr} 68$ & 13.50 \\
\hline & & Mean & 13.72 \\
\hline & $7-39-87$ & Without minor gene & 42.25 \\
\hline & $7-41-88$ & Without minor gene & 37.37 \\
\hline & $7-42-89$ & Without minor gene & 28.38 \\
\hline & $7-43-90$ & Without minor gene & 24.60 \\
\hline & & Mean & 33.15 \\
\hline
\end{tabular}


Table.3 Grain yield loss assessment in the $\mathrm{BC}_{3} \mathrm{~F}_{3}$ and $\mathrm{BC}_{3} \mathrm{~F}_{4}$ progenies of the cross

GW322 x PARULA in bread wheat

\begin{tabular}{|c|c|c|c|}
\hline Generation & Progeny & $\begin{array}{l}\text { Minor gene } \\
\text { screened }\end{array}$ & $\begin{array}{c}\text { Percent reduction } \\
\text { in yield }\end{array}$ \\
\hline \multirow{13}{*}{$\mathrm{BC}_{3} \mathrm{~F}_{3}$} & $21-27-156$ & Lr68 & 11.11 \\
\hline & $21-27-158$ & Lr68 & 9.55 \\
\hline & & Mean & 10.33 \\
\hline & $21-27-155$ & Lr34 & 12.68 \\
\hline & $21-27-157$ & Lr34 & 3.07 \\
\hline & $18-69$ & $\operatorname{Lr} 34$ & 16.62 \\
\hline & & Mean & 10.67 \\
\hline & $21-27-154$ & Lr34+Lr68 & 12.94 \\
\hline & $21-27-159$ & $\operatorname{Lr} 34+\operatorname{Lr} 68$ & 11.39 \\
\hline & & Mean & 12.16 \\
\hline & 31 & Without minor gene & 32.38 \\
\hline & $32-34$ & Without minor gene & 35.11 \\
\hline & & Mean & 33.74 \\
\hline \multirow{11}{*}{$\mathrm{BC}_{3} \mathrm{~F}_{4}$} & $31-18-102-356$ & Lr68 & 17.76 \\
\hline & $31-18-102-337$ & Lr34 & 9.72 \\
\hline & $18-122-110$ & Lr34 & 15.28 \\
\hline & 18-137-111 & Lr34 & 4.79 \\
\hline & & Mean & 9.93 \\
\hline & $31-83-102$ & $\operatorname{Lr} 34+\operatorname{Lr68}$ & 8.28 \\
\hline & $31-81-103$ & $\operatorname{Lr} 34+\operatorname{Lr} 68$ & 11.59 \\
\hline & & Mean & 9.94 \\
\hline & $31-81-103-358$ & Without minor gene & 17.82 \\
\hline & $31-81-103-359$ & Without minor gene & 46.25 \\
\hline & & Mean & 32.03 \\
\hline
\end{tabular}

Table.4 Overall yield loss assessment in back cross segregating generation of the cross

GW322 x PARULA in bread wheat

\begin{tabular}{|c|c|}
\hline Presence of genes & Percent reduction in yield \\
\hline Lr68 & 16.36 \\
Lr34 & 14.98 \\
Lr34+Lr68 & $\mathbf{1 3 . 2 7}$ \\
Absence of genes & $\mathbf{3 2 . 2 5}$ \\
\hline
\end{tabular}

In $\mathrm{BC}_{3} \mathrm{~F}_{4}$ generation (Table 3) plants with Lr34 alone and plants with Lr34 + Lr68 recorded lower reduction in yield upto 9.94 per cent. Plants with Lr68 alone recorded high reduction in grain yield per plant $(17.76 \%)$. However, plants lacking both the genes recorded very high amount of reduction in yield $(32.03 \%)$.
The idea of this investigation was to identify the effect of slow rusting genes (Lr34 and Lr68) on yield and also to identify superior recombinants for yield and its component traits having both the genes. In backcross segregating populations of the cross $\mathrm{GW} 322 \mathrm{x}$ PARULA viz., $\mathrm{BC}_{2} \mathrm{~F}_{4}, \mathrm{BC}_{3} \mathrm{~F}_{3}$ and $\mathrm{BC}_{3} \mathrm{~F}_{4}$ percent reduction in yield was assessed in 
presence and absence of slow rusting genes. In this analyses the yield losses were comparatively lower for most of the progenies with slow rusting genes in their background. However, high yield losses were observed in some progenies that were immune to the leaf rust having both slow rusting resistant genes in their background. Sayre et al., (1998) found that leaf rust caused losses irrespective of the level of resistance possessed by the cultivars.

The plants respond to inoculation with energy-demanding physiological processes, probably defense reactions, using stored host energy that otherwise would go to growth and seed production. In addition, a reduction in photosynthetic leaf area due to leaf tip necrosis pleiotropically associated with $\operatorname{Lr34}$ also can cause yield reductions.

Overall yield loss assessment considering all backcross segregating generation of the cross GW322 x PARULA was carried out (Table 4 and Fig. 1). Plants carrying Lr34 gene exhibited 14.98 per cent reduction in yield while it was only 13.27 per cent in presence of both $\operatorname{Lr} 68$ and $\operatorname{Lr} 34$ genes. In the absence of both genes overall reduction in yield was 32.25 per cent. These finding were aggrement with Singh et al., 1997, who reported in the presence of $L r 34$ reduction in yield was only 15 per cent. In the absence of $L r 34$ reduction in yield were substantially higher and ranges between 42.5 per cent to 84 per cent depending upon planting date and year.

In presence of $\operatorname{Lr} 68$ alone reduction in yield was recorded 16.36 per cent while in presence of both Lr68 and Lr34 was 13.27. Similar results was reported by Singh et al., (2001) who reported that cultivars with $\operatorname{Lr} 34$ and two to three additional genes have shown a stable environmental response and final disease ratings lower than five percent under high disease pressure and yield losses less upto 610 per cent.
These losses can be further minimised by introgression of other additive, slow rusting genes like $\operatorname{Lr67}$ gene in the background of these advanced backcross segregating populations having Lr34 and Lr68 gene in their background, to form the Lr34- complex (Singh and Rajaram, 1992). Increasing the frequency of these genes and introgression through marker assisted selection should be a useful strategy for controlling leaf rust disease and minimizing yield losses. These plants with both the genes in combination and superior in performance are the potential lines for further development of varieties, keeping in view the durability of resistance which will provided by the plants with the genes in combination.

\section{Acknowledgement}

The authors are highly thankful to ICAR-All India Co-ordinated Wheat Improvement Project, Main Agricultural Research Station, University of Agricultural Science (UAS), Dharwad for their kind support during the experiment.

\section{References}

Calpouzos, J., Roelfs, A.P., Madson, M.E., Martin, F.B., Wilcoxson, S., 1976. A new model to measure yield losses caused by stem rust in spring wheat Agric. Exp. Sta. Univ. Minnesota. Tech. Bull. 307, 1-23.

Doyle, J. J., and Doyle, J. L., 1987. A rapid isolation procedure from small quantities of fresh leaf tissue. Phytochem. Bull., 19: 11-15.

Dyck, P. L., 1987. The association of a gene for leaf rust resistance with the chromosome $7 \mathrm{D}$ suppressor of stem rust resistance in common wheat.

Herrera-Foessel, S. A., Lagudah, E. S., HuertaEspino, J., Hayden, M., Bariana, H. S., Singh, D. and Singh, R. P., 2011. New slow rusting leaf rust and stripe rust resistance genes $\mathrm{Lr67}$ and $\mathrm{Yr} 46$ are 
pleiotropic or closely linked. Theor. Appl. Genet., 122: 239-249.

Herrera-Foessel, S. A., Singh, R. P., HuertaEspino, J., Rosewarne, G. M., Sambasivam K. P., Viccars L., CalvoSalazar V., Lan Caixia and Lagudah E. S. 2012. Lr68: a new gene conferring slow rusting resistance to leaf rust in wheat. Theor. Appl. Genet., 124: 1475-1486. Genome, 29: 467-469.

Hiebert, C. W., Thomas J. B., McCallum B. D., Humphreys D. G., DePauw R. M., Hayden M. J., Mago, R., Schnippenkoetter, W. and Spielmeyer, W., 2010. An introgression on wheat chromosome 4DL in RL6077 (Thatcher*6/PI 250413) confers adult plant resistance to stripe rust and leaf rust (Lr67). Theor. Appl. Genet., 121: 10831091

Huerta-Espino, J., Singh, R. P., German, S., McCallum, B. D., Park, R. F., Chen, W. Q., Bhardwaj, S. C. and Goyeau, H., 2011. Global status of wheat leaf rust caused by Puccinia triticina. Euphytica, 179: 143-160.

Kolmer, J. A., Long, D. L. and Hughes, M. E., 2005. Physiological specialization of Puccinia triticina on wheat in the United States in. Plant Dis., 89: 1201-1206.

Marasas, C. N., Smale, M. and Singh, R. P., 2004. The Economic impact in developing countries of leaf rust resistance breeding in CIMMYT-related spring bread wheat. International Maize and Wheat Improvement Center, Mexico,
DF, p. 86.

McIntosh, R. A., Yamazaki, Y., Dubcovsky, J., Rogers J., Morris C., Appels R. and Xia, X. C., 2013. Catalogue of gene symbols for wheat. $12^{\text {th }}$ Int. Wheat Genetics Symp, pp. 8-13.

Roelfs, A. P., Singh, R. P. and Saari, E. E. 1992. Rust Diseases of Wheat: Concepts and Methods of Disease Management. CIMMYT, Mexico, DF, p. 85.

Sayre, K. D., Singh, R. P., Huerta-Espino, J., and Rajaram, S. 1998. Genetic progress in reducing losses to leaf rust in CIMMYTderived Mexican spring wheat cultivars. Crop Sci. 38:654-659.

Singh, R. P., and Huerta-Espino, J., 1997, Effect of leaf rust resistance gene Lr34 on grain yield and agronomic traits of spring wheat. Crop Sci., 37: 390-395.

Singh, R. P., and Rajaram, S., 1992. Genetics of adult-plant resistance to leaf rust in 'Frontana' and three CIMMYT wheats. Genome., 35: 24-31.

Singh, R. P., Herrera-Foessel, S., HuertaEspino, J., Bhavani, S., 2011. Race nonspecific resistance to rust diseases in CIMMYT spring wheats. Euphytica, 179: 175-186.

Singh, R. P., Mujeeb-Kazi, A. and HuertaEspino, J., 1998. Lr46: A gene conferring slow-rusting resistance to leaf rust in wheat. Phytopathology, 88: 890-894.

Singh, S. P., Jha, P. B. and Singh, D. N., 2001. Genetic variability for polygenic traits in late sown wheat genotypes. Ann. Agric. Res., 22 (1): 34-36.

\section{How to cite this article:}

Ashutosh Kumar, S.A. Desai, Suma S. Biradar, K.J. Yashavantha Kumar, P.V. Patil, V. Rudra Naik, T.N. Sathisha and Bhumika N. Patel. 2017. Genetic Studies on the Effect of Slow Rusting Genes Lr34 and Lr68 on Minimizing Grain Yield Losses in Back Cross Segregating Populations of the Cross GW322 X Parula in Bread Wheat (Triticum aestivum L.). Int.J.Curr.Microbiol.App.Sci. 6(10): 3592-3599. doi: https://doi.org/10.20546/ijcmas.2017.610.423 